\title{
ResearchArticle
}

\section{Effect of planting techniques and irrigation levels on growth and yield of wheat (Triticum aestivum L.)}

\author{
Lord Litan Debbarma, Dipak Nath and Dipankar Dey
}

\begin{abstract}
SUMMARY
The experiment was conducted at Rampur Research Farm Rampur, Dehradun, Uttarakhand, India during Nov., 2013 to April, 2014 to study the effect of planting techniques and irrigation levels on growth and yield of wheat (UP-2584). Irrigation was scheduled as per treatment based on IW (Irrigation Water): CPE (Cumulative Pan Evaporation) ratio and on critical growth stages (CGS). The treatments comprising three irrigation scheduling i.e. $1_{1}$ (irrigation at IW: CPE 0.90), $1_{2}$ (irrigation at IW: CPE1.20) and $l_{3}$ (irrigation at Critical Growth Stages) and five planting techniques i.e. Flat bed (Conventional). Raised bed, top $45 \mathrm{~cm}$ with two rows (RB 45/15). Broadcast seeding then making raised bed, top $45 \mathrm{~cm}$ (MRB 45/25). Broadcast seeding then making raised bed, top $60 \mathrm{~cm}$ (MRB 60/25). Broadcast seeding then making raised bed, top $80 \mathrm{~cm}$ (MRB 80/25). Data on agronomic traits like germination, numbers of tillers per $\mathrm{m}^{2}$, numbers of active leaves, dry matter accumulation, plant height, grain weight, 1000-grain weight, grain number/ear, number of fertile and sterile spikelet's/spike, grain yield, straw yield, biological yield and harvest index was recorded. Result showed that irrigation schedule at IW: CPE 1.20 recorded significantly highest grain yield (48.3 quintal/ha), respectively compared to rest of treatment. Consumptive water use efficiency was recorded in IW: CPE 0.90 significantly highest $(28.4 \mathrm{~kg} / \mathrm{ha}-\mathrm{cm})$, respectively as compared to IW: CPE 1.20 and CGS. Numbers of tillers $/ \mathrm{m}^{2}$, dry matter accumulation $\left(\mathrm{g} / \mathrm{m}^{2}\right)$, root weight density, 1000-grain weight in CGS levels was significantly highest over rest of the treatments.
\end{abstract}

Key Words : Wheat, Planting techniques, Irrigation levels, Growth, Yield

How to cite this article : Debbarma, Lord Litan, Nath, Dipak and Dey, Dipankar (2018).Effect of planting techniques and irrigation levels on growth and yield of wheat (Triticum aestivum L.). Internat. J. Plant Sci., 13 (2): 249-255, DOI: 10.15740/HAS/IJPS/13.2/ 249-255, Copyright@ 2018: Hind Agri-Horticultural Society.

Article chronicle : Received : 18.05.2018; Revised : 16.06.2018; Accepted : 27.06.2018

\section{MEMBERS OF THE RESEARCH FORUM}

Author to be contacted :

Lord Litan Debbarma, Krishi Vigyan Kendra, Khowai (Tripura) India

Address of the Co-authors:

Dipak Nath and Dipankar Dey, Krishi Vigyan Kendra, Khowai (Tripura) India 